\title{
Pemanfaatan E-Commerce dengan Metode FAST untuk Strategi Pemasaran pada Zerroart
}

\section{Utilization of E-Commerce with the FAST Method for Marketing Strategy on Zerroart}

\author{
Elly Yanuarti ${ }^{1}$, Agustina Merdeka Raya ${ }^{2}$, Gusti Novriyanda ${ }^{3}$ \\ 1,2,3 Institut Sains dan Bisnis Atma Luhur Pangkalpinang \\ e-mail: elly@atmaluhur.ac.id ${ }^{1}$, agustinamardekaraya@atmaluhur.ac.id², \\ gustinovriyanda@atmaluhur.ac.id ${ }^{3}$
}

\begin{abstract}
Abstrak
Penerapan teknologi dalam perdagangan dan bisnis mutlak diperlukan sebagai strategi meningkatkan penjualan dan perluasan pemasaran melalui layanan online berupa web e-commerce. Zerroart adalah salah satu distro yang berusaha memanfaatkan teknologi dalam layanan penjualannya agar dapat bersaing dan meningkatkan hasil penjualannya. Penjualan hanya dengan cara konvensional dimasa pandemi covid 19 ini dirasakan tidak dapat meningkatkan hasil penjualan dan jumlah pembelinya pun terbatas. Penelitian ini menganalisis kebutuhan dari Zerroart dalam mencapai tujuannya dan mengembangkan sebuah sistem berbasis web menggunakan model Framework for the Application of System Thinking (FAST). Metode yang digunakan dalam menganalisis menggunakan metode berorientasi objek dengan pemodelan UML. Berdasarkan hasil pengujian website e-commerce dapat digunakan dengan mudah oleh user dan transaksi realtime. Web yang dikembangkan menampilkan fitur-fitur yang sesuai dengan kebutuhan dari Zerroart dimana konsumen dapat melihat semua produk yang tersedia, melakukan pesanan dan pembayaran.
\end{abstract}

Kata Kunci: e-commerce, UML, penjualan online, Model FAST, Object Oriented

\begin{abstract}
Implementation of technology in commerce and business is absolutely necessary as a strategy to increase sales and expand marketing through online services in the form of web e-commerce. Zerroart is a distro that tries to take advantage of technology in sales services to compete and increase sales results. Sales conventional during the Covid 19 pandemic are felt to be unable to increase sales results and the number of buyers is limited. This study analyzes the needs of Zerroart in achieving its goals and develops a web-based system using the Framework for the Application of System Thinking (FAST) model. The method used in analyzing uses object-oriented methods with UML modeling. Based on the test results, the e-commerce website can be used easily by users and real-time transactions. The developed web displays features that match the needs of Zerroart where consumers can see all available products, place orders and make payments.
\end{abstract}

Keywords: e-commerce, UML, Online marketing, FAST model, Object Oriented

\section{Pendahuluan}

Akhir-akhir ini penggunaan teknologi internet semakin pesat. Internet semakin berpengaruh di dalam perdagangan atau bisnis. Penggunaan internet dalam bisnis kini berubah dari berfungsi sebagai media pertukaran informasi menjadi alat untuk aplikasi strategi bisnis seperti penjualan, pemasaran dan pelayanan terhadap pelanggan. Dalam perdagangan dan bisnis, salah satu implementasi teknologi untuk mempercepat dan meningkatkan penjualan adalah melalui layanan online yang berupa e-commerce.

E-Commerce menjadi sebuah teknologi yang dibutuhkan oleh setiap organisasi yang bergerak dibidang perdagangan dimana konsumen dapat membeli barang dengan memanfaatkan teknologi internet [1]. E-commerce dapat meningkatkan konektivitas dan interaktifitas perusahaan serta meningkatkan kekuatan pelanggan sehingga dapat meningkatkan persaingan [2]. E-commerce dapat dimanfaatkan dalam berbagai bisnis seperti penjualan kamar hotel dimana E-commerce sebagai media promosi dan transaksi dalam dan luar negeri yang dapat digunakan secara mudah dan efisien [3]. Pemanfaatan E-Commerce dirasakan juga dalam penjualan Burger Sei Putih dimana mengalami kenaikan penjualan dan keuntungan, memberikan kepuasan pelanggan sebesar $13 \%$, sarana promosi sebesar $75 \%$ dan pengembangan bisnis sebesar 12\% [4]. Selain itu industri kerajinan bordir juga memanfaatkan E-Commerce untuk membantu kegiatan promosi dan pemasaran produk [5]. 
Zerro Art merupakan sebuah distro yang sedang berkembang dan bergerak dalam bidang penjualan fashion yang meliputi kaos, kemeja, topi, sepatu, jaket dan akesesoris lainnya. ZerroArt belum memiliki sistem penjualan yang terkomputerisasi sehingga dokumentasi transaksi belum begitu baik dimana rentan terjadinya kehilangan dan kerusakan. Selain itu kendala dalam penjualan produk di Zerro Art adalah jumlah pangsa pasar yang terbatas karena penjualan produk hanya melalui penjualan langsung kepada konsumen dan promosinya pun hanya menggunakan whatsapp dimana orang yang melihatpun terbatas. Apalagi dimasa pandemi Covid-19 daya beli masyarakat semakin menurun dan masyarakat membatasi diri untuk berinteraksi langsung dengan orang lain juga berpengaruh terhadap penjualan Zerro Art. Untuk mengatasi hal tersebut sudah selayaknya Zerro Art mengambil langkah strategi pemasaran agar dapat bertahan, meningkatkan volume penjualan dan meningkatkan penyebaran pangsa pasar. Zerro Art perlu melakukan perubahan konsep pemasaran dari konvensional ke digital. Perubahan konsep pemasaran digital ini bukan berarti memindahkan toko konvensional ke bentuk digital saja namun termasuk didalamnya adalah kualitas produk, harga yang kompetitif, kemudahan, dan pelayanan yang maksimal [6]. Melalui pemasaran digital komunikasi dan transaksi dapat dilakukan secara real time dan mendunia [7].

Dalam penelitian ini penulis membuat model dan rancangan aplikasi penjualan online / web ecommerce yang akan dimanfaatkan oleh Zerro Art guna mempercepat dan meningkatkan penjualan dan memperluas pangsa pasar seperti yang sudah diterapkan di beberapa penelitian antara lain perancangan ecommerce untuk penjualan produk oleh-oleh khas Pontianak [8]. Metode yang digunakan dalam penelitian ini adalah Waterfall yang menghasilkan sistem e-commerce yang dapat menampilkan fitur yang mudah digunakan oleh konsumen yang menumbuhkan daya saing global dan memperluas pangsa pasar. Selain itu ada juga perancangan e-commerce penjualan katering [9]. Metode yang digunakan adalah Research and Development yang menghasilkan e-commerce yang dapat menjangkau pelanggan lebih mudah dan lebih luas. Selanjutnya ada perancangan website penjualan sepatu [10]. Metode yang digunakan adalah waterfall yang hasilnya adalah sebuah website yang digunakan untuk memberikan pelayanan bagi konsumen menjadi lebih baik. Dalam penelitian ini penulis tertarik mengembangkan sebuah website e-commerce menggunakan metode FAST seperti penelitian yang dilakukan oleh [11],[12],[13]. Penelitian ini diharapkan dapat bermanfaat sebagai strategi dalam meningkatkan pelayanan dan perluasan pemasaran pada ZerroArt.

\section{Metode Penelitian \\ Model Pengembangan Sistem}

Model pengembangan sistem yang penulis gunakan dalam penelitian ini adalah Framework for the Application of System Thinking (FAST). Model FAST dapat menghasilkan sistem informasi dalam waktu singkat dan kualitas yang terbaik, lebih fleksibel sehingga dapat disesuaikan dengan standar serta dapat dikembangkan dengan metode lain seperti metode berorientasi objek. Dalam penelitian ini akan diuraikan 8 tahapan dari model FAST yaitu definisi ruang lingkup, analisis masalah, analisis kebutuhan, desain logis, analisis keputusan, analisis kelayakan, desain fisik, pengujian, serta instalasi. Metode analisis dan desain dalam penelitian ini adalah metode berorientasi objek dengan pemodelan UML.

\section{Langkah-Langkah Penelitian}




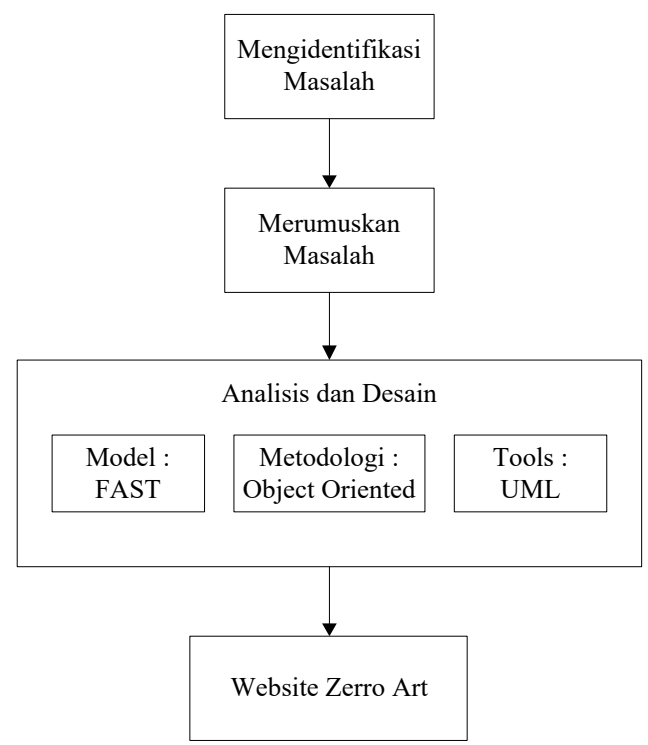

Gambar 1. Langkah-Langkah Penelitian

\section{Hasil dan Pembahasan}

Berdasarkan tahapan yang ada pada model FAST maka dapat diuraikan Ruang lingkup dalam penelitian ini adalah proses pendataan produk, proses transaksi penjualan, proses pembayaran, dan pelaporan transaksi yang ada di ZerroArt.

\section{Analisis Masalah}

Berikut yang merupakan inti dari permasalahan sistem penjualan pada penelitian ini adalah :

1. Dokumentasi transaksi belum begitu baik sehingga besar kemungkinan terjadinya kerusakan dan kehilangan data.

2. Proses transaksi masih dilakukan secara konvensional sehingga pangsa pasar dan penjualan menjadi terbatas.

3. Belum memiliki sistem yang terkomputerisasi

\section{Analisis Kebutuhan}

Adapun kebutuhan pengguna terhadap sistem yang baru adalah sebagai berikut :

1. Kebutuhan Fungsional

a. Sistem harus memiliki level akses dan mampu mengotentifikasi pengguna sesuai hak akses

b. Sistem harus dapat mengunggah, mengunduh, menyimpan, menghapus dan mencetak dokumen.

c. Sistem dapat menyajikan data dan informasi yang akurat.

d. Sistem memiliki tingkat keamanan yang baik.

e. Sistem mampu melakukan backup data.

2. Kebutuhan Non Fungsional

a. Sistem mudah digunakan dan dapat diakses dengan cepat.

b. Sistem mampu mengurangi beban kerja pegawai.

c. Adanya pelatihan penggunaan sistem yang baru.

\section{Desain Logis}

Berdasarkan kebutuhan fungsional sistem maka akan digambarkan salah satu alur kerja urutan aktifitas aktor pada sistem yang dikembangkan. 


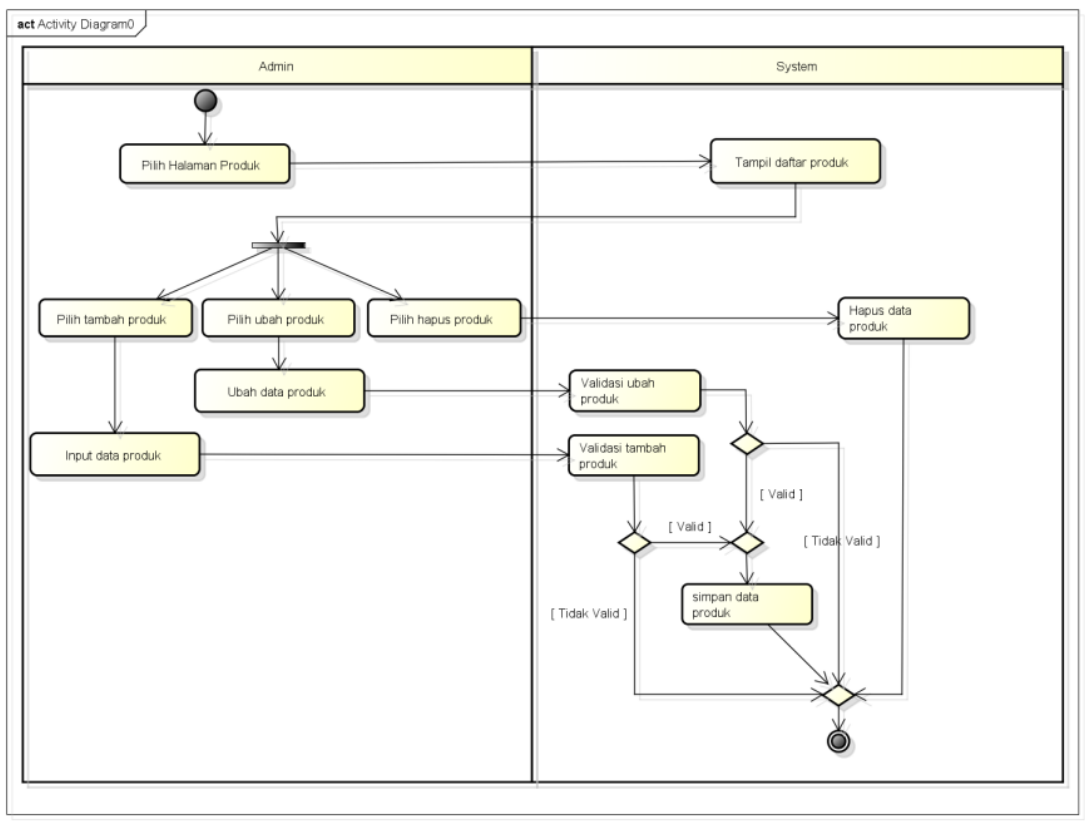

Gambar 2. Activity Diagram Kelola Data Produk

Gambar 2 diatas menunjukkan aktivitas dari sistem dari sisi admin yaitu menambah data produk. Admin memilih halaman produk, lalu pada halaman tersebut akan ditampilkan daftar produk yang sudah diinput. Jika admin memilih tambah produk dan menginput data produk baru, sistem akan memvalidasi data. Jika valid maka data produk akan disimpan oleh sistem. Jika admin memilih ubah produk dan mengubah data produk, sistem akan memvalidasi data. Jika valid maka data produk yang diubah akan disimpan oleh sistem. Jika admin memilih menghapus data produk maka sistem akan menghapus data tersebut dari database.

\section{Analisis Keputusan}

1. Sistem yang digunakan adalah sistem penjualan online.

2. Website yang dihasilkan bermanfaat untuk perluasan pangsa pasar karena transaksi yang realtime.

3. Perangkat lunak yang digunakan antara lain untuk interface menggunakan PHP dan untuk database menggunakan mySQL.

\section{Desain Fisik}

Adapun tampilan website yang dikembangkan diantaranya adalah :

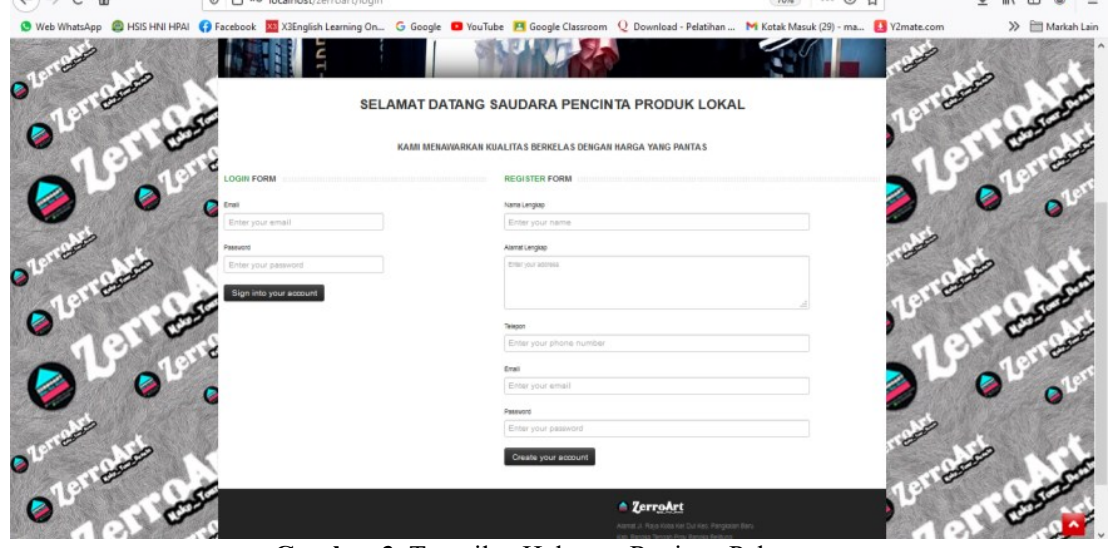

Gambar 3. Tampilan Halaman Register Pelanggan

Gambar 3 diatas menampilkan halaman yang digunakan untuk mendata atau membuat akun pelanggan baru. Tersedia Register Form bagi user baru untuk mengisi data akun dan Login Form bagi user yang sudah melakukan register. Setelah akun berhasil dibuat maka pelanggan dapat login dan melanjutkan transaksi. 


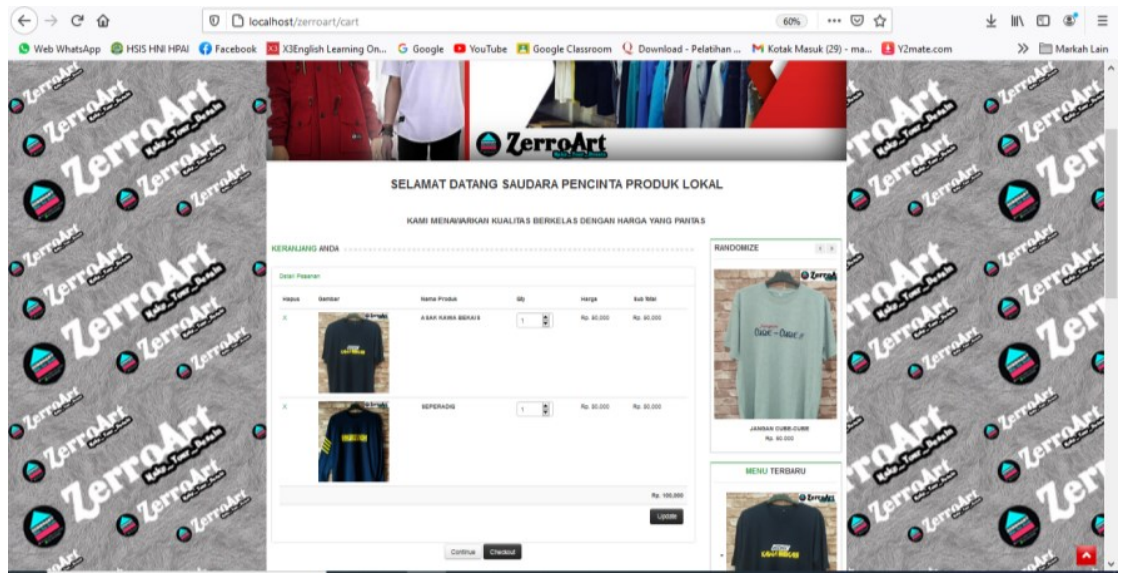

Gambar 4. Tampilan Halaman Keranjang Pelanggan

Gambar 4 diatas menunjukkan tampilan halaman keranjang pelanggan. Halaman ini berisi produkproduk yang sudah dipilih oleh pelanggan. Pelanggan dapat mengisi jumlah produk yang akan dipesan. Jika pelanggan mengklik tombol continue maka pelanggan dapat menambah produk kedalam keranjang. Jika mengklik tombol checkout maka akan tampil data pelanggan dan detail produk yang akan dipesan oleh pelanggan. Pada halaman ini juga pelanggan dapat memilih rekening untuk transfer pembayarannya seperti gambar 5. Pada gambar 6 setelah user mengklik tombol Konfirmasi Pesanan pada gambar 5 diatas akan tampil halaman Konfirmasi Pembayaran dimana menampilkan status pembayaran pesanan. Pelanggan dapat mengkonfirmasi pembayaran dengan mengupload bukti pembayarannya dan selanjutnya status pesananpun akan terupdate setelah dilakukan validasi oleh admin.

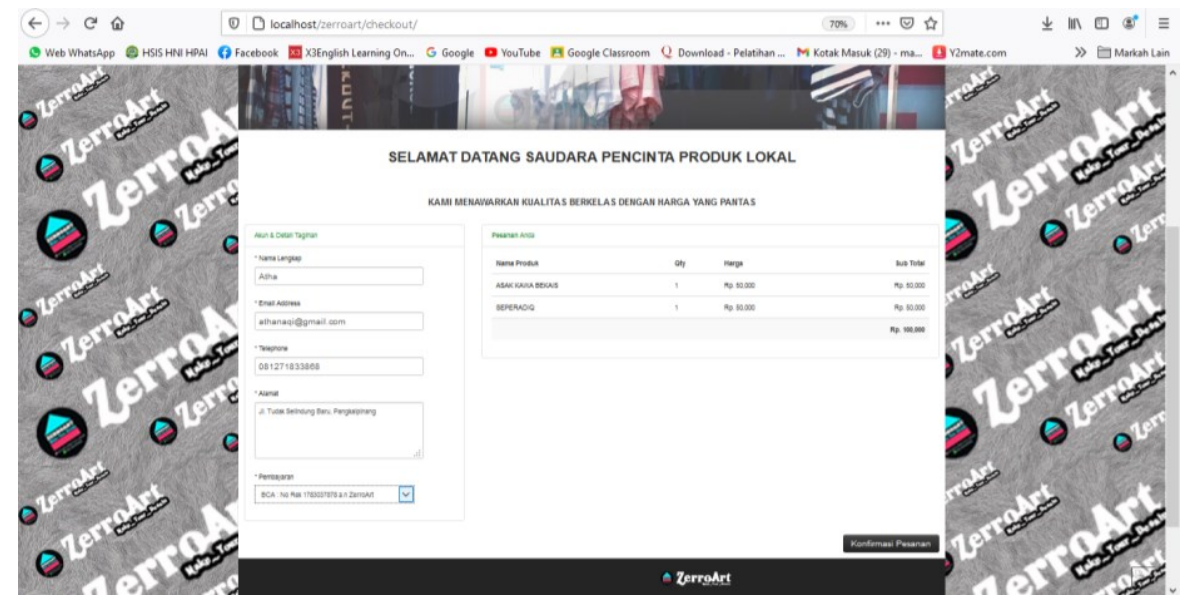

Gambar 5. Tampilan Halaman Pesanan Pelanggan

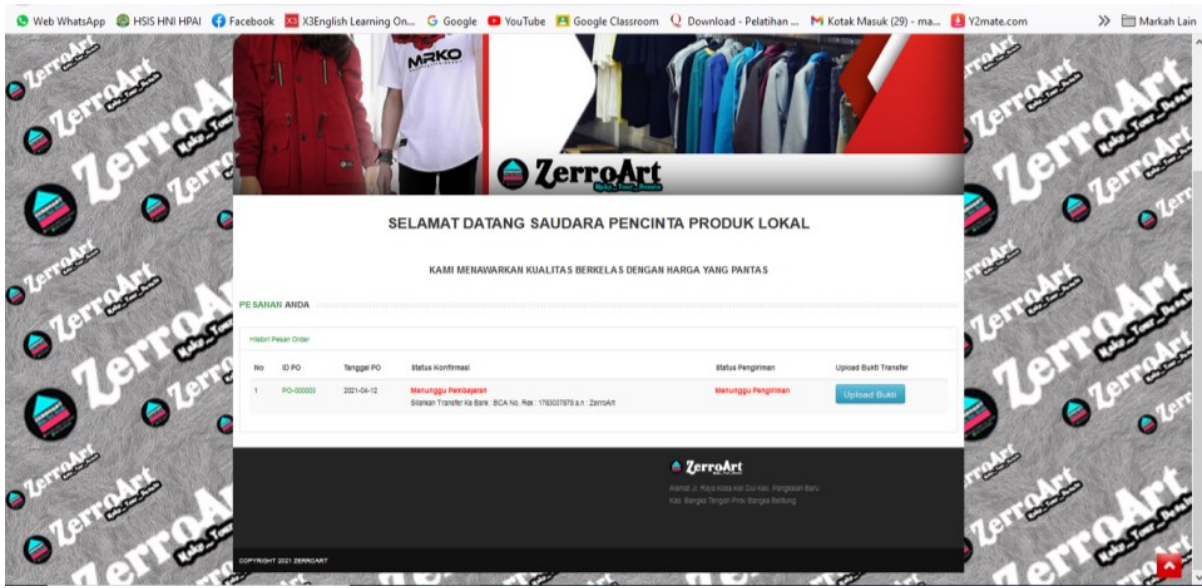

Gambar 6. Tampilan Halaman Konfirmasi Pembayaran 


\section{Pengujian}

Hasil pengujian mandiri pada halaman admin dan halaman user :

Tabel 1. Hasil Pengujian Mandiri Pada Halaman Amin

\begin{tabular}{|c|c|c|c|c|}
\hline No. & Modul & Prasyarat & Hasil yang diharapkan & Hasil Uji Coba \\
\hline 1. & Tambah Produk & $\begin{array}{l}\text { Login sebagai admin (data sudah ada } \\
\text { di database) }\end{array}$ & $\begin{array}{l}\text { Admin dapat menambah data } \\
\text { produk }\end{array}$ & OK \\
\hline 2. & Edit Produk & $\begin{array}{l}\text { Login sebagai admin (data sudah ada } \\
\text { di database) }\end{array}$ & $\begin{array}{l}\text { Admin dapat mengubah data } \\
\text { produk }\end{array}$ & OK \\
\hline 3. & Hapus Produk & $\begin{array}{l}\text { Login sebagai admin (data sudah ada } \\
\text { di database) }\end{array}$ & $\begin{array}{l}\text { Admin dapat menghapus data } \\
\text { produk }\end{array}$ & $\mathrm{OK}$ \\
\hline 4. & $\begin{array}{l}\text { Validasi Halaman } \\
\text { Pembayaran }\end{array}$ & $\begin{array}{l}\text { Login sebagai admin (data sudah ada } \\
\text { di database) }\end{array}$ & $\begin{array}{l}\text { Admin dapat memvalidasi data } \\
\text { pembayaran dari pelanggan }\end{array}$ & OK \\
\hline 5. & Daftar Pelanggan & $\begin{array}{l}\text { Login sebagai admin (data sudah ada } \\
\text { di database) }\end{array}$ & $\begin{array}{l}\text { Admin dapat menampilkan dan } \\
\text { mencari data pelanggan }\end{array}$ & OK \\
\hline 6. & Daftar Pesanan & $\begin{array}{l}\text { Login sebagai admin (data sudah ada } \\
\text { di database) }\end{array}$ & $\begin{array}{l}\text { Admin dapat menampilkan dan } \\
\text { mencari data pesanan pelanggan }\end{array}$ & OK \\
\hline 7. & Cetak Laporan & $\begin{array}{l}\text { Login sebagai admin (data sudah ada } \\
\text { di database) }\end{array}$ & $\begin{array}{l}\text { Admin dapat mencetak laporan } \\
\text { penjualan berdasarkan periode } \\
\text { yang dipilih }\end{array}$ & OK \\
\hline
\end{tabular}

Tabel 2. Hasil Pengujian Mandiri Pada Halaman User

\begin{tabular}{|c|c|c|c|c|}
\hline No. & Modul & Prasyarat & Hasil yang diharapkan & Hasil Uji Coba \\
\hline 1. & Register & - 20 & $\begin{array}{l}\text { User dapat membuat akun } \\
\text { pelanggan }\end{array}$ & $\mathrm{OK}$ \\
\hline 2. & Login & Register & $\begin{array}{l}\text { User dapat masuk ke halaman } \\
\text { website }\end{array}$ & OK \\
\hline 3. & Daftar Produk & $\begin{array}{l}\text { Login sebagai user (data sudah ada di } \\
\text { database) }\end{array}$ & $\begin{array}{l}\text { User dapat memilih dan } \\
\text { menampilkan data produk }\end{array}$ & OK \\
\hline 4. & Keranjang & $\begin{array}{l}\text { Login sebagai user (data sudah ada di } \\
\text { database) }\end{array}$ & $\begin{array}{l}\text { User dapat memilih produk untuk } \\
\text { dimasukkan ke keranjang belanja }\end{array}$ & OK \\
\hline 5. & Halaman Tagihan & $\begin{array}{l}\text { Login sebagai user (data sudah ada di } \\
\text { database) }\end{array}$ & $\begin{array}{l}\text { User dapat melihat tagihan } \\
\text { pesanan dan melakukan checkout }\end{array}$ & OK \\
\hline 6. & $\begin{array}{l}\text { Konfirmasi } \\
\text { Pembayaran }\end{array}$ & $\begin{array}{l}\text { Login sebagai user (data sudah ada di } \\
\text { database) }\end{array}$ & $\begin{array}{l}\text { User dapat mengupload bukti } \\
\text { pembayaran dan melihat status } \\
\text { pesanan }\end{array}$ & OK \\
\hline 7. & Histori Pesanan & $\begin{array}{l}\text { Login sebagai user (data sudah ada di } \\
\text { database) }\end{array}$ & $\begin{array}{l}\text { User dapat menampilkan histori } \\
\text { pesanan }\end{array}$ & $\mathrm{OK}$ \\
\hline
\end{tabular}

\section{Kesimpulan}

Dari pembahasan yang telah diuraikan diatas maka dapat diambil kesimpulan bahwa penerapan Ecommerce mengubah kegiatan pemesanan secara konvensional menjadi pemesanan secara digital atau perdagangan online. Web E-Commerce yang dikembangkan dengan model FAST mudah digunakan dan sesuai dengan kebutuhan dari Zerroart. Berdasarkan hasil pengujian, pelanggan dengan mudah mendapatkan informasi tentang produk dan melakukan pemesanan serta mengupload bukti pembayarannya. Web e-commerce mendukung transaksi real time, sebagai media promosi yang dapat memperluas pangsa pasar, meningkatkan layanan dan diharapkan dapat meningkatkan hasil penjualan.

\section{Daftar Pustaka}

[1] S. Mumtahana, Hani Atun, Nita and A. W. Tito, "Pemanfaatan Web E-Commerce untuk Meningkatkan Strategi Pemasaran,” khazanah Inform., vol. 3, no. 1, pp. 6-15, 2017, [Online]. Available: http://journals.ums.ac.id/index.php/khif/article/view/3309/2784.

[2] M. Pradana, "Klasifikasi Bisnis E-Commerce di Indonesia," MODUS, vol. 27, no. 2, pp. 163-174, 2015.

[3] N. M. Widani, A. P. Abiyasa, and G. S. Darma, "Menguji Ketajaman Implementasi E-Commerce Dalam Penjualan Kamar Hotel di Bali," J. Manaj. dan Bisnis, vol. 16, no. 2, pp. 79-98, 2019.

[4] T. A. S. Mahzura, "Pemanfaatan E-Commerce Dalam Peningkatan Penjualan Pada Burger Sei Putih Kota Medan," J. Ekon. Bisnis Manaj. Prima, vol. 2, no. 1, pp. 65-80, 2020.

[5] D. L. Fithri, A. P. Utomo, and F. Nugraha, "Pemanfaatan E-Commerce Populer Untuk Optimalisasi Pemasaran Produk Pada KUB Bordir Kurnia Kudus,” J. Simetris, vol. 8, no. 2, pp. 819-824, 2017.

[6] S. P. Sari, "Strategi Meningkatkan Penjualan di Era Digital," Sci. J. Reflect. Ekon. Accounting, 
Manag. Bus., vol. 3, no. 3, pp. 291-300, 2020, doi: 10.5281/zenodo.3930698.

[7] T. Pradiani, "Pengaruh Sistem Pemasaran Digital Marketing Terhadap Peningkatan Volume Penjualan Hasil Industri Rumahan,” J. Ilm. Bisnis dan Ekon. Asia, vol. 11, no. 2, pp. 46-53, 2018, doi: 10.32812/jibeka.v11i2.45.

[8] S. Kosasi, "Perancangan Sistem E-Commerce Untuk Memperluas Pasar Produk Oleh-Oleh Khas Pontianak," Snastia, vol., no., pp. 110-119, 2015.

[9] M. Sidik, "Perancangan dan Pengembangan E-commerce dengan Metode Research and Development," Jtiust, vol. 04, no. 1, pp. 99-107, 2019.

[10] I. D. Lesmono, "Rancang Bangun Sistem Informasi Penjualan Sepatu Berbasis Website Dengan Metode Waterfall," Swabumi, vol. 6, no. 1, pp. 55-62, 2018, doi: 10.31294/swabumi.v6i1.3316.

[11] W. Warjiyono, F. Fandhilah, and A. N. Rais, "Metode FAST \& Framework PIECES: Analisis \& Desain Sistem Informasi Penjualan Berbasis Website," Indones. J. ..., vol. 6, no. 2, pp. 172-181, 2020, [Online]. Available: https://ejournal.bsi.ac.id/ejurnal/index.php/ijse/article/view/8988.

[12] Sarwindah and E. Yanuarti, "Pengembangan Prototype Sistem E-Commerce pada Ajun Elektronik dengan Metode FAST," J. Sisfokom (Sistem Inf. dan Komputer), vol. 9, no. 2, p. 281, 2020, doi: 10.32736/sisfokom.v9i2.871.

[13] R. Nyarso Listiyono and R. Koesdijarto, "Sistem Informasi Alat Medis Berbasis Web Dengan Metode FAST di Rumah Sakit RKZ Surabaya,” Konvergensi, vol. 16, no. 1, pp. 25-33, 2020. 